\title{
Tracing female subversion in Buchi Emecheta's The Joys of Motherhood: Reading motherhood as a patriarchal institution
}

\author{
Himakshi Kashyap
}

PhD Research Scholar, Department of English, Krishna Kanta Handique State Open University, Assam, India

Received: 22 Sep 2021; Received in revised form: 20 Oct 2021; Accepted: 25 Oct 2021; Available online: 31 Oct 2021

C2021 The Author(s). Published by Infogain Publication. This is an open access article under the CC BY license

(https://creativecommons.org/licenses/by/4.0/).

\begin{abstract}
Human relationships are determined by power structures which are erected on cultural, social, physical, economic or political basis. The man-woman relationship is considered as a hierarchical one placing the male at the supreme position and the female at the lowest, the weakest. Such a distinction is measured from both the gendered and the biological perspective. The patriarchal and patrilineal social structures throughout the world treat women as the recipient of male consent and relegate them towards the state of passivity, selflessness, caring and dependency. To legitimize these supposed situational perceptions about women; patriarchy installs different socio-cultural institutions among which motherhood is one. The reproductive power rather than the woman herself, is very essential for the man to continue his reign of manhood down through his descents for which female bodies are treated as nothing but some child bearing machines. This is done in such a neat and obvious manner that the woman herself doesn't realize the politicization and objectification of her own body. In fact, motherhood becomes and remains the only denominator of successful womanhood under a patriarchal regime. The Nigerian author Buchi Emecheta highlights all such issues concerning women in a tribal social background especially through the character of Nnu Ego. Nnu Ego who got dishonored due to her infertility in her first marriage, had to try her fate in a second marriage with someone she thought she would never have chosen as her husband. She was bestowed with motherhood with a good number of children. She even brought them up with all care and aspired to be happy at a successful completion of the mostly cherished motherhood. But, it appeared treacherous and a bitter outcome ruined all her hope and pride, thus a dismantling is done of the institution of motherhood making space for a line of questions aroused immediately against its legitimacy. This paper proposes to make a study of motherhood as a patriarchal institution or rather one patriarchal imposition that enables men to utilize female bodies for their own sake, thereby exploiting and silencing them. It will peep through the illusioned life of Nnu Ego for that sake as a victim of body politics in the consolidated institution of motherhood. Such a discussion will further help in understanding the myths lurking around motherhood and the female body in a male dominated society particularly in Africa and in the world as a whole.
\end{abstract}

Keywords-body politics, female subversion, fertility, motherhood.

\section{INTRODUCTION}

Patriarchy in all facets of its understanding tends to maintain a pyramidal power structure sustaining the difference in identities between man and woman. The supremacy of man is ingrained in patriarchy to such a level that they become the one to define their counterpart's role and destiny of life. But, it must be kept in mind that patriarchy is not a system created by God. It is simply a cultural construct promoted by men to superimpose their 
significance in the society about which Adrienne Rich in the forward to her book "Of Woman Born" comments like this: "...patriarchy is equivalent to culture and culture to patriarchy" (Rich, 10). This imposition is so obviously performed that no questions are raised about its legitimacy until and unless women become aware of their essence. Patriarchy, though the male power is at the peak in common, differs in connotation from culture to culture, from society to society and so on. This leads to a great deal of variations in the experience of its subjects. To justify the male supremacy, so many strategies are undertaken by patriarchy among which motherhood is one.

Motherhood is a natural physical capacity owned by women. It is the power bestowed upon them to bring new life which is very important for continuation of the existence of the human race on the earth. It will be more proper to say that not exactly motherhood but the reproductive power is something which is natural to women. Motherhood is actually a socio-cultural construct whereby this very female power is promoted under conditions and they are prescribed with the task of mothering along with all other feminine roles in the society. However, the ideology of motherhood is understood differently across social class, race, ethnicity and culture. As an institution, "motherhood involves the potential role of a woman as wife, as mother, as daughterin-law and so on" as stated by Biswajit Ghosh in one of his essays entitled "The Institution of Motherhood: A Critical Understanding". It is a stereotype created by the patriarchy. Girls are taught to accept motherhood as their destiny of life for which they are required to undergo a heterosexual relationship through another social institution called marriage. The age old tendency to subvert the female power is strengthened and legitimized through motherhood because, if only someone is incapable of begetting a child, their identity gets reduced to some adjectives like 'barren', 'infertile', 'unfortunate'. Moreover, if the children prosper in life the credit is attributed to the father, not the mother though she sacrifices the whole lot of her life for their cause. The story of motherhood is "... unmentioned in the histories of conquest and serfdom, war and treaties, exploration and imperialism-has a history, it has an ideology, it is more fundamental than tribalism or nationalism" (Rich, 34). Women are expected to be nourishing, caring, pure, selfless and loving as a mother and perform her duties unconditionally and without any complaint. The male interest to sustain their legacy needs the female body. But, this dependency is veiled by stereotyping female reproductivity and thereby imprisoning all strengths, aspirations and passions of women so as to glorify the supreme status of the male. They are conditioned to think that her only duty remains in taking care of her children, pleasing her husband both mentally and physically, maintaining a clean image of an ideal mother and justifying all her limited activities to be important and significant to herself. Thus, motherhood remains a patriarchal institution in almost all the societies which, to cite Adrienne Rich in her book of Woman Born...."has ghettoized and degraded female potentialities." (13).

This paper is an attempt to exemplify the patriarchal conditioning of motherhood in the specific tribal society of Africa as portrayed in the novel "The Joys of Motherhood" by one of the prominent African novelists Buchi Emecheta.

\section{TEXTUAL ANALYSIS}

The Joys of Motherhood was first published in 1979 where, as the critic Marie Umeh comments, "Emecheta breaks the prevalent portraitures of African writing...It must have been difficult to draw provocative images of African motherhood against the already existing literary models, especially on such a sensitive subject". Emecheta explores here a very different world of pain, suffering, loss of the self, loss of self proximity, misery, illusion, alienation, sympathy and disregard experienced by all women in varied intensity as rewards after becoming a mother. This novel is being researched here through an analytical and descriptive method to find out how the protagonist and other women are held captive in the institution of motherhood by the age-old traditional beliefs celebrated by patriarchy.

Nnu Ego, the protagonist of the novel is one of those common women who unquestionably believe that the essence of her life remains in her capability to beget children for her husband. Her mother though was burdened by non-marital pregnancy, kept her stand about deciding the fate of the child depending on its gender i.e if it was a girl, it would stay with her husband Agbadi and if not, it would go to her father's place. The girl child is Nnu Ego who stayed with her father after her mother's death with all possible loyalty and respect until she was married off to Amatokwu. But, her first marriage proved to be unsuccessful as she couldn't conceive. Her husband brought another woman to prove the validity of his manhood and Nnu Ego found no other way than to stay back at her father's place. She was horrified at her incapability for conceiving as she exclaims:"What am I going to do, Amatokwu?"(31). It echoes the prejudice she nurtured regarding women who don't become mothers. She believes that "when one grows old, one needs children to look after one" (38) and readily agreed to move to a far place called Lagos with the hope to have "a string of 
children" (39) with a man as his senior wife. She realized that she would never have loved a man like Naife, her new husband but what if "this man made her pregnant, would that not be an untold joy to her people?" (44). She was destined to become a mother not only because she aspired to be one, but mostly because she desperately wanted to prove herself to the people of her community. She worshipped her Chi by sacrificing animals and her wish was fulfilled as she became mother to three sons and two sets of twin daughters. But, the reality of motherhood was far from satisfactory. Nnu Ego, the wife of a laundryman had not only to struggle for food, clothes and livelihood, but mostly for the education of her children.

Nnu Ego was regarded as a fortunate and happy mother by dint of her having three sons. It was not her, but the whole community's belief that only begetting male children is a sign of worthy motherhood. She was doomed to that belief and was very enthusiastic to help her sons to get educated and well settled in their lives. She worked hard to manage with the little housekeeping money provided by her husband; even she herself started earning by selling cigarettes, paraffin, and firewood and so on. At the beginning, she often rebelled against her situation, but finally she had to submit to her husband who clearly told her: "...I am not an ideal husband...But, woman, you have to look after your child. That at least is a woman's job."(86). She even had to accept that "a man is never ugly and never old. He matures with age and is dignified" (71) as because her husband never denied marrying and inheriting new women only by dint of his manhood. He always stayed outside the house doing his jobs and when returned, the only thing he did was to impregnate his wives and spend all the money in drinking and merrymaking. It is very common to observe in every society that in comparison to the mother, the father remains detached from the children that is discussed by Rich like this: "To "father" a child suggests above all to beget, to provide the sperm which fertilizes the ovum. To "mother" a child implies a continuing presence; lasting at least nine months... motherhood is earned." (12). He even made Adaku, the inherited wife, opt to become a prostitute rather than spending life in poverty. Nnu Ego broke down in grief to realize her fate and even tried to take shelter in her father's place. But, her father too, the upholder of patriarchy, denied her proposal by saying that her only place was at her husband's side as he gave her the children. Rather, she should behave like a male friend to him and supervise his young wives (158) proving how patriarchy is so demanding for a woman. Her hope for peace of mind and content shifted from her father, her husband to her children, especially the sons about whom she dreamt of becoming great personalities in the future. But, things didn't turn up as per her wish. Two of her sons settled themselves in foreign lands, one in the US and one in Canada to pursue their dreams notwithstanding what will happen to the family. She was surrounded by her daughters, the youngest son, the son-in-laws and other well wishers in Lagos, but her hope for only one single response from the two emigrated sons never got fulfilled which depressed and devastated her soul. She never expected anything from her daughters like she did from her sons. But, she was not also hypnotized by the dictate of patriarchy regarding the birth of a girl child. She took her last sigh at Ibuza, her father's place with no one by her side. A mother to so many children died unhappily proving the illegitimacy and inaccuracy of the institution of motherhood.

A woman may never need a man who is only capable of giving her children and a life doomed in poverty. She neither is born only to become a mother or a wife nor aspires to be regarded as a mere plaything in the hands of the man. The society and the culture where she is situated, teaches her to be one. They are conditioned to grow and respond to all those expected roles positively and end up shaping further a world predominated with male concerns. A mother even can't be happy because of her children only. Her happiness may be subjected to other personal needs and hopes rather than nurturing the children which is unfortunately dismissed by the patriarchy. Moreover, they are not even given any chance to listen to the echo of their hearts as independent individuals. Emecheta states towards the end of the novel about this crude reality after the death of Nnu Ego that "She had never really made many friends, so busy had she been building up her joys as a mother" (224) that brought nothing to her in return. Nnu Ego and many women like her are prisoners of their own flesh and blood as she exclaims: "The men make it look as if we must aspire for children or die. That's why when I lost my first son I wanted to die, because I failed to live up to the standard expected of me by the males in my life..."(187). She in her thoughts announced a war against all those misinterpretations regarding the birth of girl children in the institutionalized space of motherhood: "But did not a woman have to bear the woman-child who would later bear the sons? who made the law that we should not hope in our daughters?" (186-187).

Nnu Ego is a strong woman just like the others in her community as they are capable enough of sailing the boat of life on their own by working hard, going to any extent to look after their children without even any help from their male counterparts. But, they are not treated to be strong or rather not let to realize their worth and it is done through the patriarchal codifications of everything related to a woman, not excluding the body. The body due to its 
capability of reproduction is objectified and utilized by the men to its best as "...all they were interested in were male babies to keep their names going" (186).

\section{CONCLUSION}

Thus, the study proves that motherhood is nothing but a social construct intended to fulfill the concerns of patriarchy whereby female bodies are commodified by putting the burden of child bearing and objectified as mere sex-mates. Patriarchy determines when and how motherhood in a woman's life will occur and how will it influence their lives. Women are bound to abide by the rules and traditions of their societal positioning; otherwise accusations will be posed as rewards. Not only the specific African Igbo society is contaminated with all these malprojections regarding women, but further studies can be pursued in different socio-cultural landscapes in the world to find out only the same as patriarchy is overwhelming and overpowering.

\section{REFERENCES}

[1] Emecheta, Buchi. (1994). The Joys of Motherhood. Heinemann Publishers (Pty) Limited. South Africa. print

[2] Ghosh, Biswajit. (December, 2016). "The Institution of Motherhood: A Critical Understanding". Retrieved from https://www.researchgate.net/publication/312076821

[3] Rich, Adrienne. (1976). Of Woman Born Motherhood as Experience and Institution. W. W. Norton \& Company. INC. New York

[4] https://en.m.wikipedia.org/wiki/The_Joys_of_Motherhood

[5] https://www.scielo.br/scielo.php?script=sci_arttext\&pid=S21 $\underline{75-80262015000200093}$ 